\title{
Effect of Calcium Carbonate Filler on Self-Compacting Concrete Using Different Aggregate Sizes
}

\author{
Wasiu John, Agbawhe Okeoghene Oghenekume, Tuleun Lawrence Zahemen
}

\begin{abstract}
In this research work, the effect of Calcium Carbonate Filler was studied on the compressive strength and the workability of self-compacting Concrete (SCC) at different grades (M60, M65 and M70) and different coarse aggregate sizes $(6.3 \mathrm{~mm}, 10 \mathrm{~mm}$ and $20 \mathrm{~mm})$. Calcium Carbonate Filler (Limestone powder) and Rice Husk Ash (RHA) were added in percentages of $2.5 \%$ and $5 \%$ to check its effect on the workability and strength properties of SCC and Normally Vibrated Concrete. Experimental investigations were carried out on SCC and normally vibrated concrete (NVC) samples of grade M60, M65 and M70 using different aggregate sizes of $6.3 \mathrm{~mm}, 10 \mathrm{~mm}$ and $20 \mathrm{~mm}$. The workability test results obtained showed values within specification. The compressive and Tensile strengths for SCC (with powder and $2.5 \%$ RHA) are higher than that with powder and 5\% RHA and NVC. Generally, the use of Calcium Carbonate Filler improved the strength and densities for SCC design mix and decreased its workability. It is concluded that the use of SCC with designed Fillers ratio and RHA $(\leq \mathbf{5 \%})$ will improve the strength properties of SCC.
\end{abstract}

Index Terms-Compressive Strength, Calcium Carbonate Filler, Rice Husk Ash, Self-Compacting Concrete, Super Plasticizer.

\section{INTRODUCTION}

Self-Compacting Concrete (SCC) is a highly flow-able concrete type that spreads and compacts into every corner of a formwork purely under the action of its own weight without the need for any form of mechanical vibration. It was first developed in Japan in the year 1988 due to the drastic reduction in the number of skilled workers and site operatives that the Japanese construction industry experienced in the 1980's [1]. The use of SCC in their construction projects ultimately required less skilled labour for the mixing, placement, vibration and compaction of the concrete. Furthermore, using SCC, they were able to achieve long lasting and more efficient concrete structures without any form of vibration. In the preparation and mixing of SCC, it is necessary to make use of plasticizers (water reducers) so as to ensure high mobility of the concrete mix and to prevent segregation of the concrete mix. Plasticizers are water-reducing chemicals and as the name implies; their major function is to reduce the water content of a concrete mixture while maintaining constant workability. The resultant effect of the reduced water content in the concrete mix is increased strength and durability in the concrete.

Published on September 5, 2019.

J. Wasiu, Afe Babalola University, Ado-Ekiti, Nigeria, Johnwasiu@abuad.edu.ng

O. O Agbawhe, Afe Babalola University, Ado-Ekiti, Nigeria okeoghene96@gmail.com

L.Z. Tuleun, University of Ilorin, Nigeria. tuleun@gmail.com.
The addition of fillers is also necessary in the mixing of SCC. This is because fillers help to prevent the occurrence of voids in the concrete mix especially after mixing and pouring considering that SCC compacts under the action of its own weight. Also, fillers aid in reducing the setting time of the concrete mix as well as obtaining considerable strength a short while after being cast with the concrete mix still being flow able during mixing. Examples of fillers commonly used in SCC are fly ash, limestone (L.S) powder, rice husk ash, silica fume, glass and quartzite. For the purpose of this research, lime stone powder and rice husk ash have been used.

\section{Literature Review}

The composition of SCC mixes includes substantial proportions of fine-grained inorganic materials and this gives possibilities for utilization of mineral admixtures, which are currently environmental waste with no practical applications and are costly to dispose [2]. The technology of SCC production is based on adding or partially replacing Portland cement with amounts of fine material such as fly ash, blast furnace slag, and silica fume without modifying the water content compared to common concrete. This process changes the rheological behavior of the concrete [3]. Generally, SCC has to have proper flow ability and viscosity, so that the coarse aggregate can float in the mortar without segregating. The use of viscosity modifying agents (an example is polysaccharides) and stabilizers is common in the preparation of SCC as SCC is very sensitive to any fluctuations in water content. An example of the mix proportions used in SCC as compared to conventional concrete is illustrated in Figure 1 below.

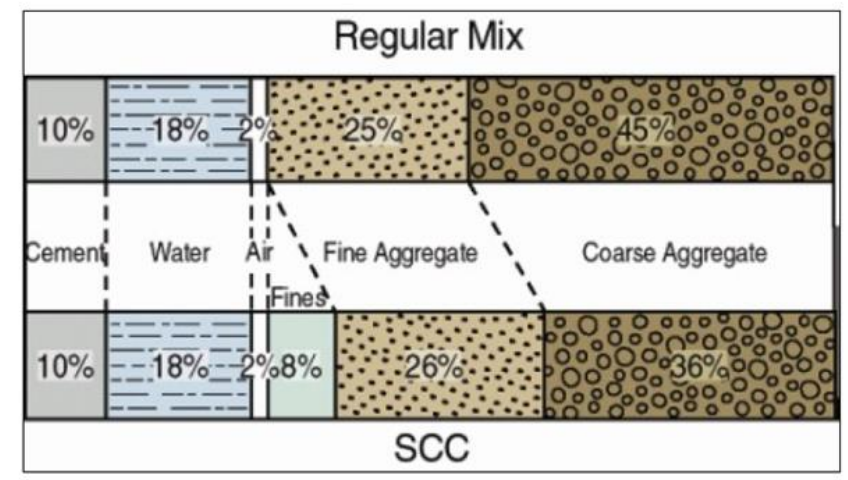

Fig. 1: Materials Used in Regular Concrete and Self-Compacting Concrete by Absolute Volume [4]

According to Valeria et al [5], marble powder has proven to be a very effective additive in cohesiveness of concrete mix. This may be due to its high fineness. It can be used for other ultra-fine mineral additives such as silica fumes which can improve the cohesiveness of concrete mixture. Marble 
powder effect in SCC are noticeable even at early days of curing due to its filler ability. In summary, the flow properties of SCC depend heavily on powder particle size, shape, surface morphology and internal porosity in addition to factors such as mixing regimen, sequence of admixture addition, and water/superplasticizer content [6], [7].

Practically, all types of structural constructions are possible with the use of SCC. The use of SCC shortens the construction period while ensuring the quality and durability of concrete. This is because it allows faster placement of concrete and less finishing time leading to improved productivity.

Okamura [8] proposed a new type of concrete which could be compacted into the corners of a formwork purely by means of its own weight. Prior to this, in the year 1986, Okamura had begun a research project aimed at determining the flow ability and workability of this concrete which was later named self-compacting concrete. He found that the self-compacting characteristic of this concrete is majorly affected by the mix proportions of the concrete and the characteristics of the materials used in the preparation. In his study; Okamura fixed the coarse aggregate content to $50 \%$ of the solid volume and the fine aggregate content to $40 \%$ of the mortar volume so that self-compactability could be achieved easily by adjusting the water to cement ratio and super plasticizer dosage only.

Ozawa [9] was one of the various researchers who started independent research work on SCC in a bid to improve its characteristics after it was first introduced by Okamura. He successfully developed SCC on his own for the first time in the summer of 1988. An open experiment on SCC was held a year later at the University of Tokyo in front of over 100 researchers and engineers as a result of which intensive research later begun in many places, especially in research institutes of large construction companies and at the University of Tokyo. He created the first sample of selfcompacting concrete using readily available materials. He succeeded in analyzing the workability of SCC and was able to obtain a highly work-able SCC mix with the use of various types of super plasticizers. It was discovered that the SCC mix had great permeability and was proper for situations requiring rapid placement of concrete. Using the $\mathrm{V}$-funnel test, he examined the viscosity of the SCC mix. He later conducted further experiments were focused on examining the physical and chemical effect of mineral admixtures, such as fly ash and blast furnace slag (slag cement), on the flowing ability and segregation resistance of SCC. He discovered when Portland cement was partially replaced with fly ash and blast furnace slag; the flowing ability of SCC improved extraordinarily. After trying various proportions of admixtures, he was able to establish that $10-20 \%$ of fly ash and $25-45 \%$ of blast furnace slag (slag cement), by mass, was optimum for obtaining the best flowing ability and strength characteristics of SCC.

Chemical admixtures were added to materials found in conventional concrete (cement, aggregates, and water) by Kuroiwa [10] to improve the viscosity and deformability of the concrete. The resulting concrete was called superworkable concrete and it exhibited excellent deformability and resistance to segregation. The concrete completely filled heavily reinforced formworks without the use of vibrators.
Laboratory tests were carried out on the concrete and it was discovered that the concrete had superior properties in its fresh state and exhibited excellent durability even after hardening. Due to its properties, it was considered as suitable for projects involving heavily reinforced areas and it was later engaged in the construction of a 20-story building. The concrete was placed in the center-core from basement to the third floor. The building was designed as a hybrid structure with the reinforced concrete core surrounded by a steel mantle. The maximum diameter used for the reinforcement bars was 2 inches and the formworks were very congested. Ready mixed concrete plants situated near the construction site produced approximately $2000 \mathrm{~m}^{3}$ of super-workable concrete, which was placed successfully.

The following are the characteristics of SCC in its fresh state:

a. Flowing Ability: This is the ability of the selfcompacting concrete to flow on its own, under the action of its own weight; without the action of any external influence or assistance and completely fill all areas and corners of the formwork into which it is placed.

b. Segregation Resistance: This refers to the existence of sufficient viscosity within the concrete mix such that, all particles of the concrete mix are consistent and homogenous without the visible separation of the concrete constituents. The existence of segregation resistance prevents heavy bleeding of the concrete mix and sinking of coarse aggregates.

c. Passing Ability: This is the ability of the concrete to pass around and between reinforcements and open spaces within the formwork where it is placed; without blocking or separation of the constituents while completely filling the form.

\section{MATERIALS AND METHODS}

\section{A. Materials}

The materials used for this research work are locally available Ordinary Portland Cement (Dangote Brand), river sand, granite, mineral (limestone powder, rice husk ash) and chemical admixtures (super plasticizer i.e. SP430). It is worthy of note that the chemicals used in this research work are of commercial grade.

\section{1) Cement}

The cement used for this work is Ordinary Portland Cement (OPC) of grade 42.5R (Dangote brand) obtained from Ado-Ekiti Metropolis. It is the most common type of cement in use in the Nigerian construction industry. It was ensured that cement of the same grade and from a single company was used throughout the duration of this work.

\section{2) Super Plasticizer (SP 430)}

The super plasticizer used in this research is SP 430 which is a high range water reducing admixture obtained from PureChem Lagos in Nigeria. It is mainly made of sulphonated naphthalene polymers and is a brown liquid solution which disperses instantly in water as shown in Fig. 2. The physical properties of the super plasticizer are shown in Table I. 
TABLE I: PHYSICAL PROPERTIES OF SP 430

\begin{tabular}{ll}
\hline \hline Appearance: & Brown Liquid \\
\hline Specific Gravity: & $1.18 @ 25^{\circ} \mathrm{C}$ \\
Chloride Content: & Nil to BS 5075/BS:EN934 \\
Air Entrainment: & Less than $2 \%$ \\
\hline \hline
\end{tabular}

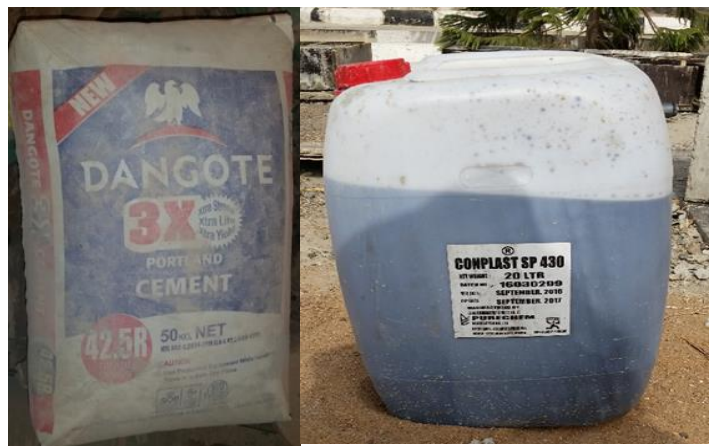

Fig. 2: Dangote Cement and Super plasticizer

\section{3) Limestone Powder}

The limestone powder used for this research work is calcium carbonate $\left(\mathrm{CaCO}_{3}\right)$ filler (Quest two brand) as Shown in Fig. 3 obtained from Ado-Ekiti, Nigeria.

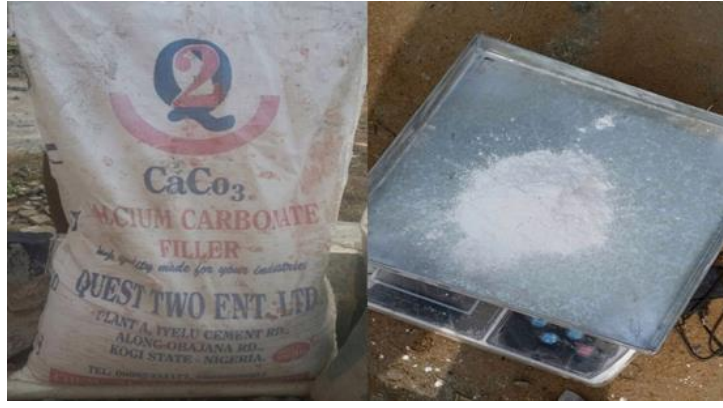

Fig. 3: Limestone Powder

\section{4) Rice Husk Ash}

The Rice Husk used for this research work was collected from Maiduguri, Northern part of Nigeria and was locally prepared by burning under controlled conditions to obtain the Ash as shown in Fig. 4. This was applied in the range of $2-5 \%$.

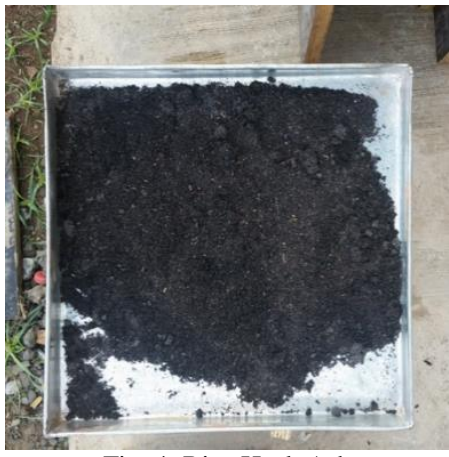

Fig. 4: Rice Husk Ash

5) Aggregate

a) Coarse Aggregate

The coarse aggregate used for this research work is locally available granite stones which were separated into three categories as follows:

- $\quad 5 \mathrm{~mm}$ to $6.30 \mathrm{~mm}$ sized granite stones
$10 \mathrm{~mm}$ sized granite stones

$14 \mathrm{~mm}$ to $20 \mathrm{~mm}$ sized granite stones

b) Fine Aggregate

The fine aggregate used for casting all concrete specimens is locally available river sand devoid of any organic impurities. A sieve analysis was carried out on the river sand and the bulk density was determined to be 1404 $\mathrm{Kg} / \mathrm{m} 3$. The maxi-mum aperture size of the river sand is $3.35 \mathrm{~mm}$. The river sand was covered when not in use to preserve the natural moisture content and to prevent bulking of the river sand which could occur as a result of trapped unsuitable moisture content in the sand.

\section{6) Water}

The water used for mixing and curing of concrete was potable borehole water. It was ensured that the water was free from any impurities such as oils, acids, alkalis, sugar, salts and organic materials or other substances that may be destructive to concrete or steel.

\section{B. Methods}

The Methods adopted in this research work includes:

(a) Separation of Coarse Aggregates: The coarse aggregates were separated into 3 categories thus; 14 $20 \mathrm{~mm}, 10 \mathrm{~mm}$ and $<10 \mathrm{~mm}$. This was done by shaking the sieves manually and separating into three different groups the aggregates that were retained on the 14 and $20 \mathrm{~mm}$ sieves; the $10 \mathrm{~mm}$ sieve and the 5 and $6.30 \mathrm{~mm}$ sieves. Fig. 5 shows the separation of aggregates sizes using the sieve shaker.

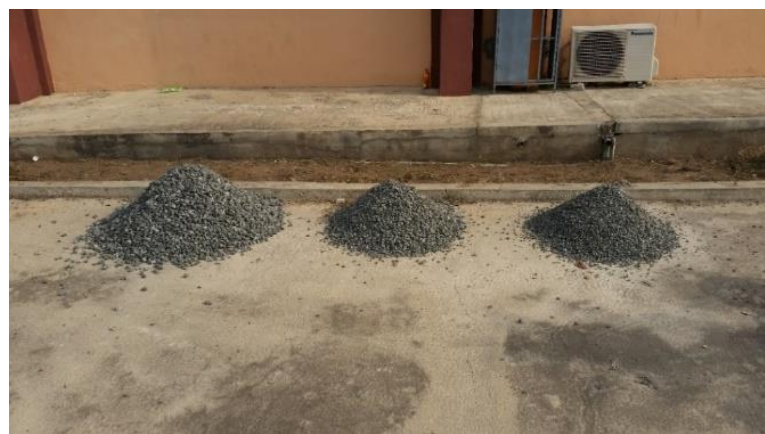

Fig. 5: (From Left to Right) 14 to $20 \mathrm{~mm}$ Sized Granite, 10mm Sized Granite and 5 to $6.30 \mathrm{~mm}$ Sized Granite

(b) Concrete Mix Design: The SCC was designed using the Nan Su et al [1] method of design. The concrete is designed using the maximum size of aggregate for each aggregate group. The concrete is also designed for the characteristic strengths $60 \mathrm{~N} / \mathrm{mm}^{2}, 65 \mathrm{~N} / \mathrm{mm}^{2}$ and $70 \mathrm{~N} / \mathrm{mm}^{2}$ as shown in Table II. Mixing of Concrete: The materials for the casting of both SCC and NVC was weighed and mixed thoroughly on a non-absorbent surface to prevent loss of water and loss of volume of the other materials.

(c) Chemical Composition of Materials: The chemical composition of RHA, calcium carbonate filler and cement is compared with the recommendations of ASTM C618-78 [11] as shown in Tables III and IV.

(d) Workability Tests: Workability tests carried out includes slump cone, V-Funnel Test and L-Box Test. They are carried out according to the specifications of BS EN 123508 [12], BS EN 12350-9 [13] and BS EN 12350-10 [14] respectively. Because of its ease of operation and 
portability, the slump flow test is the most widely used method for evaluating concrete consistency both in the laboratory and on construction sites. The concrete slump test is an empirical test that measures the workability of fresh concrete. The concrete flows as is expected. When the concrete is no longer in motion, the diameter of the concrete spread is measured and recorded as the slump as shown in Fig. 6.

TABLE II: MIX DESIGN FOR SCC USING THE NAN SU METHOD

\begin{tabular}{|c|c|c|c|c|c|c|c|}
\hline $\begin{array}{c}\text { Concrete } \\
\text { Grade }\end{array}$ & $\begin{array}{l}\text { Aggregate } \\
\text { Size }\end{array}$ & Cement & $\begin{array}{l}\text { Calcium Carbonate } \\
\text { Filler }\end{array}$ & $\begin{array}{l}\text { Fine } \\
\text { Aggregate }\end{array}$ & $\begin{array}{l}\text { Coarse } \\
\text { Aggregate }\end{array}$ & $\begin{array}{l}\text { Super Plasticizer } \\
(\mathrm{SP430})\end{array}$ & $\begin{array}{l}\text { Water Binder } \\
\text { (W/B) Ratio }\end{array}$ \\
\hline M60 & $6.3 \mathrm{~mm}$ & 1 & 0.04 & 1.69 & 1.48 & 0.02 & 0.30 \\
\hline M60 & $10 \mathrm{~mm}$ & 1 & 0.04 & 1.69 & 1.48 & 0.02 & 0.30 \\
\hline M60 & $20 \mathrm{~mm}$ & 1 & 0.04 & 1.69 & 1.48 & 0.02 & 0.30 \\
\hline M65 & $6.3 \mathrm{~mm}$ & 1 & 0.02 & 1.55 & 1.37 & 0.02 & 0.29 \\
\hline M65 & $10 \mathrm{~mm}$ & 1 & 0.02 & 1.55 & 1.37 & 0.02 & 0.29 \\
\hline M65 & $20 \mathrm{~mm}$ & 1 & 0.02 & 1.55 & 1.37 & 0.02 & 0.29 \\
\hline M70 & $6.3 \mathrm{~mm}$ & 1 & 0.01 & 1.42 & 1.25 & 0.02 & 0.29 \\
\hline M70 & $20 \mathrm{~mm}$ & 1 & 0.01 & 1.42 & 1.25 & 0.02 & 0.29 \\
\hline
\end{tabular}

TABLE III: CHEMICAL COMPOSITION OF CALCIUM CARBORNATE FILLER AND RHA

\begin{tabular}{|c|c|c|c|}
\hline $\begin{array}{c}\text { Mineral } \\
\text { Composition }\end{array}$ & $\begin{array}{c}\text { Cement } \\
(\%)\end{array}$ & $\begin{array}{c}\text { Calcium Carbonate } \\
\text { Filler } \\
(\%)\end{array}$ & $\begin{array}{c}\text { RHA } \\
(\%)\end{array}$ \\
\hline Lime $(\mathrm{CaO})$ & 60 to $67 \%$ & $55.76 \%$ & 2.10 \\
\hline Silica $\left(\mathrm{SiO}_{2}\right)$ & 17 to $25 \%$ & $1.40 \%$ & 85.7 \\
\hline Alumina $\left(\mathrm{Al}_{2} \mathrm{O}_{3}\right)$ & 3 to $8 \%$ & $0.70 \%$ & 0.58 \\
\hline Iron oxide $\left(\mathrm{Fe}_{2} \mathrm{O}_{3}\right)$ & 0.5 to $6 \%$ & $0.17 \%$ & 1.22 \\
\hline Magnesia (MgO) & 0.1 to $4 \%$ & $0.10 \%$ & 0.39 \\
\hline $\begin{array}{c}\text { Sulphur trioxide } \\
\left(\mathrm{SO}_{3}\right)\end{array}$ & 1 to $3 \%$ & $0.91 \%$ & 0.11 \\
\hline $\begin{array}{c}\text { Loss on ignition } \\
\text { (L.O.I) }\end{array}$ & $1.73 \%$ & $40.60 \%$ & 5.81 \\
\hline Phosphorus (P) & - & - & 0.35 \\
\hline $\mathrm{CaSO}_{4}$ & - & - & 0.06 \\
\hline $\begin{array}{c}\text { Alkalies }\left(\mathrm{Na}_{2} \mathrm{O}+\right. \\
\left.\mathbf{K}_{2} \mathbf{O}\right)\end{array}$ & $\begin{array}{l}0.5 \text { to } \\
1.3 \%\end{array}$ & - & 3.52 \\
\hline
\end{tabular}

TABLE IV: POZZOLANIC PROPERTIES OF RHA IN ACCORDANCE WITH ASTM C618-78

\begin{tabular}{ccccc}
\hline \hline Chemical Pozzolan (\%) & Class C & Class N & Class F & RHA \\
\hline $\mathrm{SiO}_{2}+\mathbf{A l}_{\mathbf{2}} \mathbf{O}_{\mathbf{3}}+\mathrm{Fe}_{2} \mathbf{O}_{3}$ & $>50$ & $>70$ & $>70$ & 87.5 \\
$\mathrm{SO}_{3}$ & $<4$ & $<5$ & $<5$ & 0.11 \\
$\mathbf{M g O}_{\mathbf{N a} O}$ & $<5$ & $<5$ & $<5$ & 0.39 \\
$\mathrm{Na}_{2} \mathbf{O}$ & $<1.5$ & $<1.5$ & $<1.5$ & 3.52 \\
Loss on ignition & $<6$ & $<10$ & $<2$ & 5.81 \\
\hline \hline
\end{tabular}

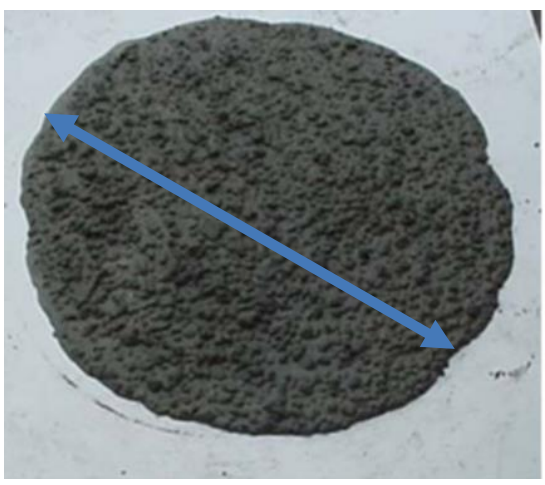

Fig. 6: Slump Test

V-funnel test: The V-funnel test is used to access the viscosity and filling ability of SCC. The V-funnel apparatus is made from metal which is not liable to rusting and it is fitted with a watertight gate at its base. The major principle of this test is to determine the amount of time taken for SCC to flow out of the $\mathrm{V}$ - funnel.

L-box test: The L-box test is used to determine the extent to which concrete is subjected to blocking by reinforcements. The apparatus consists of an L-shaped rectangular sectioned box with a vertical and horizontal section which is separated by a moveable gate in front of which vertical lengths of reinforcement bars are fitted. The sliding gate is closed and the vertical section of the L-box is filled with about 14 liters of concrete after which the gate is lifted and the concrete is allowed to flow out into the horizontal section through the spaces around the reinforcement bars. Apparent blocking of coarse aggregates behind the reinforcement bars can be detected visually. When the concrete stops flowing; the height, $H_{1}$ of the concrete in the vertical section of the L-box is measured and recorded. Also, the height, $\mathrm{H}_{2}$ of the concrete in the horizontal section is measured and recorded. The blocking ratio, $H_{1} / H_{2}$ is then calculated. If the concrete is horizontal at rest and it flows as freely as water, then the blocking ratio $H_{1} / H_{2}=1$. Therefore, the closer the blocking ratio is to unity, the better the workability. Table $\mathrm{V}$ shows the acceptance criteria by EFNARC [15].

(a) Compressive Strength Test: Compressive strength is defined as the capacity of a material or structure to withstand or resist forces or loads tending to reduce in size. It is the maximum strength that the concrete can hold prior to failure. The $100 \times 100 \times 100 \mathrm{~mm}$ cubes was tested in accordance with BS EN 12390-3 [16]. Fig. 7 shows the Compression Testing Machine with capacity of $2000 \mathrm{kN}$ in action.

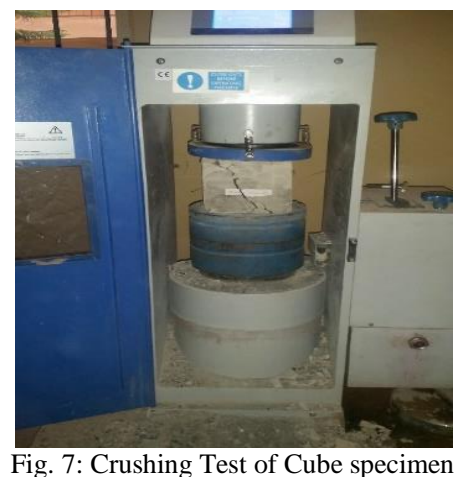

(b) Split Tensile Test: The split tensile test is also known as the indirect tension test and is a traditional test method for measuring the tensile strength of concrete. The test consists of the application of a diametric compressive load along the entire length of a concrete cylinder until failure occurs. This loading induces tensile stresses on the plane containing the applied load. Split tensile test strength was carried out on concretes based on BS EN 12390-6 [17] using 75 by 150 $\mathrm{mm}$ cylindrical specimen. The split tensile strength was 
determined at 28 days of curing.

TABLE V: ACCEPTANCE CRITERIA FOR SCC

\begin{tabular}{cc|cc}
\hline \multirow{2}{*}{ Test } & \multirow{2}{*}{ Unit } & \multicolumn{2}{|c}{ Typical range of values } \\
\cline { 3 - 4 } & & Minimum & Maximum \\
\hline Slump & $\mathrm{mm}$ & 650 & 800 \\
V-funnel test & $\mathrm{Sec}$ & 6 & 12 \\
V-funnel at $\mathbf{T}_{\mathbf{5} \text { minutes }}$ & $\mathrm{Sec}$ & 6 & 15 \\
L-box test & $\mathrm{H}_{2} / \mathrm{H}_{1}$ & 0.8 & 1.0 \\
\hline \hline
\end{tabular}

\section{RESULTS AND DISCUSSION}

\section{A. Composition of Materials}

The compositions of ordinary Portland cement, limestone powder and rice husk ash as shown in Table III revealed that calcium carbonate filler has an excellent binding properties comparable with that of cement. This is due to the high percentage of Lime $(55.76 \%)$. The presence of Lime also improves the density of the specimen. The pozzolanic potentials of RHA is also compared with the recommendations of [11] as shown in Table IV. RHA has high pozzolanic potential of about $87.5 \%$ due to high Silica $\left(\mathrm{SiO}_{2}\right)$ content in the composition.

\section{B. Workability Test}

The workability tests carried out includes slump cone test, V-funnel Test and L-Box Test. The slump test results are presented in Table VI and also compared with specifications of [10]. The SCC mix containing Calcium Carbonate Filler (Limestone powder) and RHA (as an additive) exhibited high slump spread of 732-740 mm. Similarly, mix design with only Limestone exhibit slump value in the range of $710-725 \mathrm{~mm}$. This is significant as it indicates that the SCC (with Limestone) and SCC (with powder + RHA) are highly workable, and it is within the acceptable criteria for SCC. From Table VII, it can be observed that the average results from the V-funnel and L-Box test is in line with the acceptable range specified by [10] showing that the SelfCompacting Concrete mix is workable. The V-funnel and LBox test results also revealed slower workability with mix containing Calcium Carbonate Filler. As can be seen from Table VI, the slump values for SCC mixes of grade M60 prepared with $10 \mathrm{~mm}$ and $20 \mathrm{~mm}$ coarse aggregates exhibited $0.69 \%$ and $2.07 \%$ lower slump spreads respectively than the SCC mix produced with $6.3 \mathrm{~mm}$ coarse aggregates. For grade M65, it is $0.41 \%$ and $4.76 \%$ lower than the SCC mix produced with $6.3 \mathrm{~mm}$ coarse aggregates. However, for the SCC mixes of grade M70, the slump is $2.77 \%$ higher than that with Limestone powder only. Generally, there is better flow ability with $6.3 \mathrm{~mm}$ aggregate sizes.

TABLE VI: AVERAGE SLUMP AT DIFFERENT GRADES AND AGGREGATE SIZE

\begin{tabular}{cccc}
\hline SCC & MAXIMUM COARSE & \multirow{2}{*}{ ADDITIVE } & SLUMP \\
GRADE & AGGREGATE SIZE & & VALUE \\
\hline
\end{tabular}

\begin{tabular}{lclc}
\hline & $(\mathrm{mm})$ & & $(\mathrm{mm})$ \\
\hline M60 & 6.3 & Limestone & 725 \\
M60 & 10 & Limestone & 720 \\
M60 & 20 & Limestone & 710 \\
M65 & 6.3 & Limestone & 724 \\
M65 & 10 & Limestone & 732 \\
M65 & 20 & Limestone & 700 \\
M70 & 6.3 & Limestone & 726 \\
M70 & 10 & Limestone & 730 \\
M70 & 20 & Limestone & 720 \\
M70 & 20 & Limestone, Rice & 740 \\
M70 & 20 & husk ash (2.5\%) & \\
& & Limestone, Rice & 732 \\
\hline
\end{tabular}

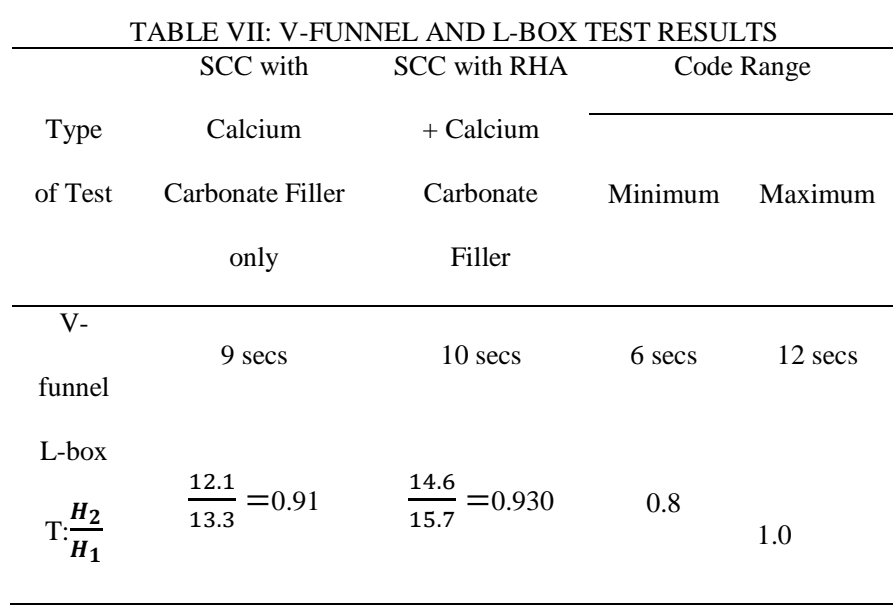

\section{Compressive Strength Test Results for SCC}

The results summary of the average compressive strength of SCC (with Calcium Carbonate Filler only), SCC (with Calcium Carbonate Filler + RHA) at different grades (M60, M65 and M70) and Normally Vibrated Concrete (NVC) are presented in Tables VIII, IX, X and XI respectively. The compressive strength at 28 days curing for SCC prepared with $10 \mathrm{~mm}$ aggregates using RHA $(2.5 \%)$ at grade M60 are $1.99 \%$ and $1.2 \%$ respectively and higher than SCC (with filler only) and SCC (with filler + 5\% RHA) of same grade. Similarly, for grade M65, the range is 3.6-16.7\% higher; and $\mathrm{M} 70$, the range is $1.68 \%-8.5 \%$ higher than other mix design as shown in Figs. 8, 9, 10 and 11 respectively. The addition of RHA generally, increases strength of SCC mix but slightly decreases upon the addition of RHA up to 5\%. This reduction is about $1.68 \%$ for grade $\mathrm{M} 70$. This reduction may be an indication of optimum addition of RHA not to exceed $5 \%$ in SCC design mix. All SCC design mix studied have higher compressive strength at 28 days curing than NVC. The range is about $8.5-14 \%$ higher. The average densities for SCC (with Calcium Carbonate Filler only), SCC (with Calcium Carbonate Filler + RHA) at different grades (M60, M65 and M70) and Normally Vibrated Concrete (NVC) are $2695.5 \mathrm{Kg} / \mathrm{m}^{3}, 2536.3 \mathrm{Kg} / \mathrm{m} 3,2556.1 \mathrm{Kg} / \mathrm{m}^{3}$ and 2434.5 $\mathrm{Kg} / \mathrm{m}^{3}$ respectively. This is within $2300-2800 \mathrm{Kg} / \mathrm{m}^{3}$ recommended by [18].

TABLE VIII: COMPRESSIVE STRENGTH OF SCC AT GRADE M60 WITH DIFFERENT AGGREGATE SIZES

\begin{tabular}{cccccccccc}
\hline \multirow{2}{*}{ No. of days } & \multicolumn{3}{c}{ SCC with powder only } & \multicolumn{3}{c}{ SCC with powder and RHA(2.5\%) } & \multicolumn{3}{c}{ SCC with powder and RHA(5\%) } \\
\cline { 2 - 9 } & M60 (6.3mm) & $\begin{array}{c}\text { M60 } \\
(10 \mathrm{~mm})\end{array}$ & $\begin{array}{c}\text { M60 } \\
(20 \mathrm{~mm})\end{array}$ & M60 (6.3mm) & $\begin{array}{c}\text { M60 } \\
(10 \mathrm{~mm})\end{array}$ & $\begin{array}{c}\text { M60 } \\
(20 \mathrm{~mm})\end{array}$ & M60 (6.3mm) & $\begin{array}{c}\text { M60 } \\
(10 \mathrm{~mm})\end{array}$ & $\begin{array}{c}\text { M60 } \\
(20 \mathrm{~mm})\end{array}$ \\
\hline 7 & 44.1 & 32.9 & 34.5 & 46.3 & 35.1 & 42 & 45.2 & 33.4 & 40.1 \\
14 & 46.2 & 60.3 & 48.4 & 48.7 & 64.1 & 58.1 & 46.9 & 62.2 & 57.0 \\
21 & 52.4 & 67.0 & 63.2 & 54.7 & 69.8 & 66.1 & 53.1 & 68.3 & 61.1 \\
28 & 62.3 & 73.8 & 71.8 & 65.7 & 75.3 & 74.3 & 62.3 & 74.4 & 68.2 \\
\hline
\end{tabular}


TABLE IX: COMPRESSIVE STRENGTH OF SCC AT GRADE M65 WITH DIFFERENT AGGREGATE SIZES

\begin{tabular}{|c|c|c|c|c|c|c|c|c|c|}
\hline \multirow[b]{2}{*}{ No. of days } & \multicolumn{2}{|c|}{ SCC with powder only } & & \multicolumn{3}{|c|}{ SCC with powder and RHA(2.5\%) } & \multicolumn{3}{|c|}{ SCC with powder and RHA(5\%) } \\
\hline & M65 (6.3mm) & $\begin{array}{c}\text { M65 } \\
(10 \mathrm{~mm})\end{array}$ & $\begin{array}{c}\text { M65 } \\
(20 \mathrm{~mm})\end{array}$ & M65 (6.3mm) & $\begin{array}{c}\text { M65 } \\
(10 \mathrm{~mm})\end{array}$ & $\begin{array}{c}\text { M65 } \\
(20 \mathrm{~mm})\end{array}$ & M65 (6.3mm) & $\begin{array}{c}\text { M65 } \\
(10 \mathrm{~mm})\end{array}$ & $\begin{array}{c}\text { M65 } \\
(20 \mathrm{~mm})\end{array}$ \\
\hline 7 & 36.5 & 45.6 & 42.9 & 57.0 & 59.0 & 58.0 & 53.0 & 55.4 & 57.0 \\
\hline 21 & 45.2 & 62.1 & 62.4 & 66.0 & 67.0 & 64.0 & 65.5 & 67.0 & 63.3 \\
\hline 28 & 63.5 & 65.0 & 67.1 & 70.0 & 78.0 & 74.9 & 67.7 & 75.2 & 71.3 \\
\hline
\end{tabular}

TABLE X: COMPRESSIVE STRENGTH OF SCC AT GRADE M70 WITH DIFFERENT AGGREGATE SIZES

\begin{tabular}{|c|c|c|c|c|c|c|c|c|c|}
\hline \multirow[b]{2}{*}{ No. of days } & \multicolumn{2}{|c|}{ SCC with powder only } & \multicolumn{4}{|c|}{ SCC with powder and RHA $(2.5 \%)$} & \multicolumn{3}{|c|}{ SCC with powder and RHA $(5 \%)$} \\
\hline & M70 (6.3mm) & $\begin{array}{c}\text { M70 } \\
(10 \mathrm{~mm})\end{array}$ & $\begin{array}{c}\text { M70 } \\
(20 \mathrm{~mm})\end{array}$ & $\begin{array}{c}\text { M70 } \\
(6.3 \mathrm{~mm})\end{array}$ & $\begin{array}{c}\text { M70 } \\
(10 \mathrm{~mm})\end{array}$ & $\begin{array}{c}\text { M70 } \\
(20 \mathrm{~mm})\end{array}$ & $\mathrm{M} 70(6.3 \mathrm{~mm})$ & $\begin{array}{c}\text { M70 } \\
(10 \mathrm{~mm})\end{array}$ & $\begin{array}{c}\text { M70 } \\
(20 \mathrm{~mm})\end{array}$ \\
\hline 7 & 35.9 & 46.4 & 37.6 & 59 & 57 & 60 & 57 & 59.8 & 61.2 \\
\hline 21 & 43.4 & 55.3 & 62.6 & 67 & 78.2 & 71.9 & 64.8 & 72 & 77 \\
\hline 28 & 74.4 & 76.4 & 78.1 & 71 & 83.5 & 81.8 & 70.2 & 82.1 & 78.6 \\
\hline
\end{tabular}

TABLE XI: COMBINED COMPRESSIVE STRENGTH NVC AT DIFFERENT GRADES

Combined NVC Compressive Strength (N/mm²) for (M60, M65, M70, All-in Aggregates)

\begin{tabular}{cccc} 
No. of days & M60 & M65 & M70 \\
\hline 7 & 36.3 & 44.7 & 39.5 \\
14 & 44.3 & 50.5 & 52.7 \\
21 & 56.6 & 60.7 & 66.1 \\
28 & 63.5 & 71.4 & 72.8 \\
\hline
\end{tabular}

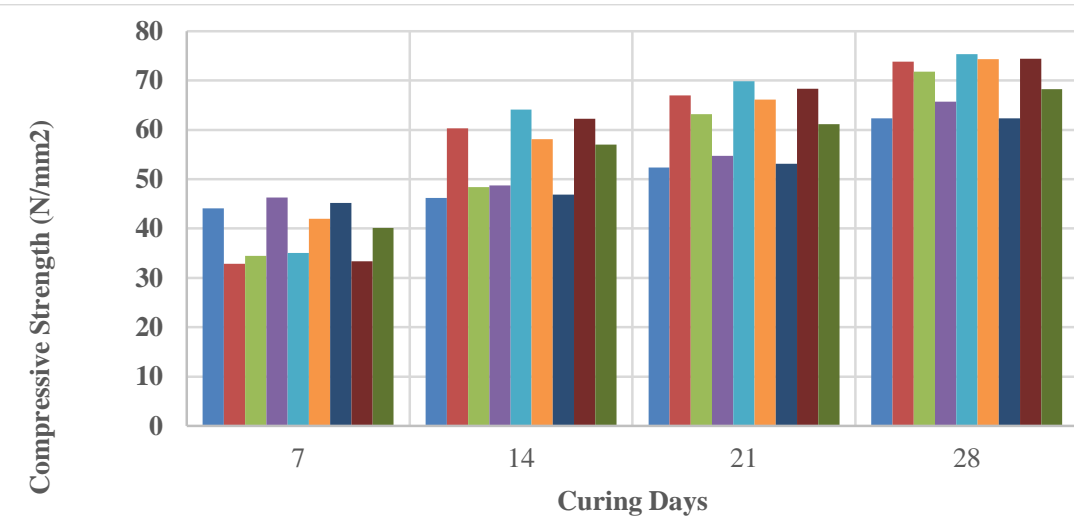

- SCC with Powder, M60 (6.3mm)

SCC with powder M60 (10 mm)

- SCC with powder M60 (20 mm)

n SCC powder+RHA(2.5\%) M60 (6.3mm)

- SCC powder+RHA(2.5\%) M60 (10mm)

- SCC powder+RHA(2.5\%) M60 (20mm)

- SCC powder+RHA(5\%) M60 (6.3mm)

- SCC powder+RHA (5\%) M60 (10mm)

n SCC powder+RHA(5\%) M60 (20mm)

Fig. 8: Variation of Compressive strength with different aggregate sizes and types of SCC at grade M60

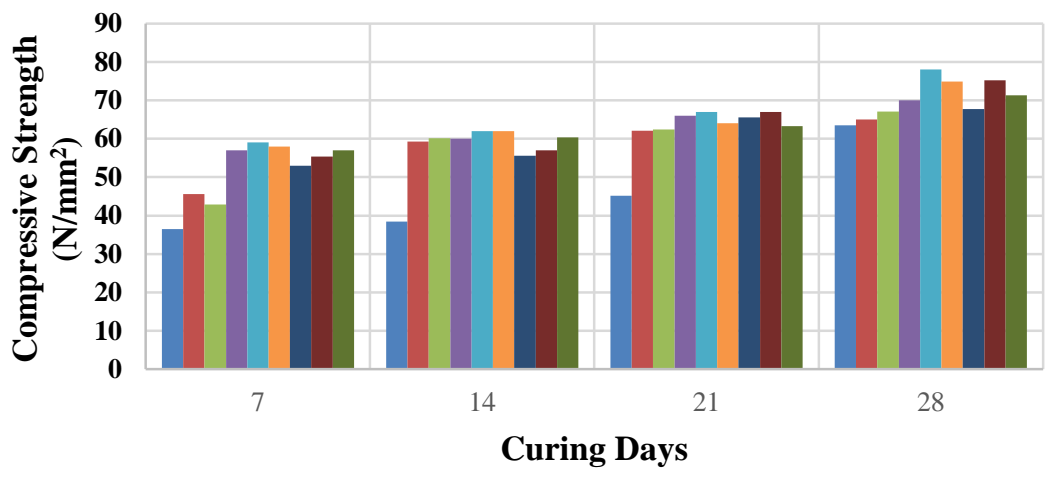
- SCC with powder, M65 $(6.3 \mathrm{~mm})$ $\mathrm{SCC}$ with powder, M65 $(10 \mathrm{~mm})$ SCC with powder, M65 $(20 \mathrm{~mm})$
nSCC powder + RHA $(2.5 \%), \operatorname{M65}(6.3 \mathrm{~mm})$ - SCC powder + RHA $(2.5 \%), \operatorname{M65}(10 \mathrm{~mm})$ - SCC powder + RHA $(2.5 \%), \operatorname{M65}(20 \mathrm{~mm})$ - SCC powder + RHA(5\%), M65 $(6.3 \mathrm{~mm})$ - SCC powder + RHA(5\%), M65 $(10 \mathrm{~mm})$ - SCC powder + RHA(5\%), M65 $(20 \mathrm{~mm})$

Fig. 9: Variation of Compressive strength with different aggregate sizes and types of SCC at grade M65

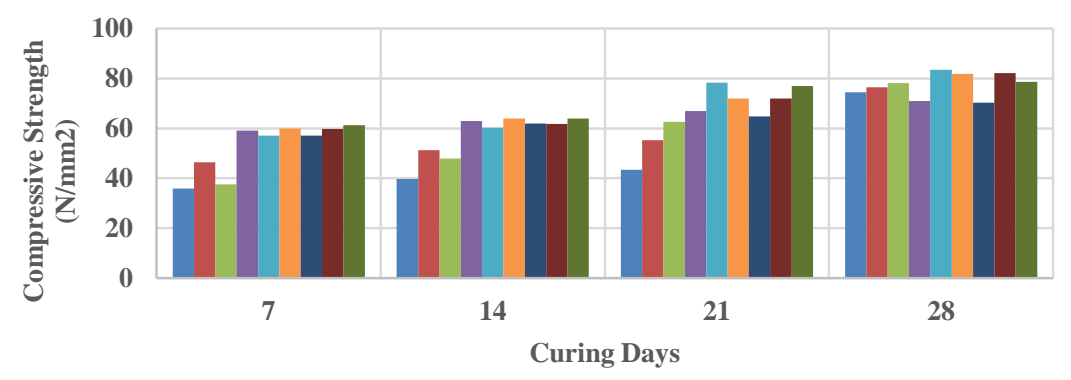
- SCC withpowder, M70 (6.3 mm) - SCC withpowder, M70 (10 mm) - SCC withpowder, M70 (20 mm) - SCC powder + RHA (2.5\%), M70 (6.3 mm) SCC powder + RHA $(2.5 \%)$, M70 $(10 \mathrm{~mm})$ nCC powder + RHA $(2.5 \%)$, M70 $(20 \mathrm{~mm})$ - SCC powder + RHA $(5 \%), \operatorname{M70}(6.3 \mathrm{~mm})$ - SCC powder + RHA (5\%), M70 (10 mm) - SCC powder + RHA (5\%), M70 (20 mm)

Fig. 10: Variation of Compressive strength with different aggregate sizes and types of SCC at grade M70 


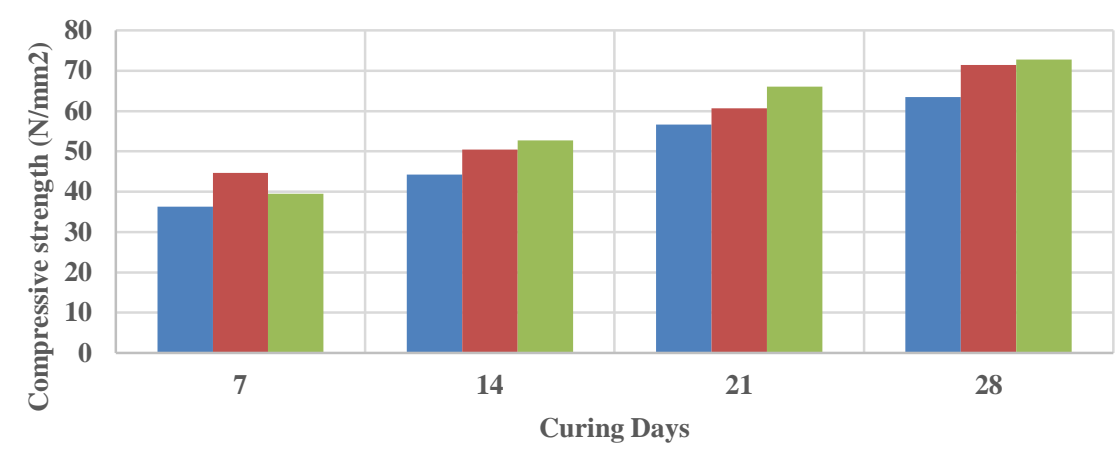

- NVC M60 (All-In-Aggregates)

- NVC M65 (All-In- Aggregates)

- NVC M70 (All-In- Aggregates)

Fig. 11: Variation of Compressive strength with different aggregate sizes and types of SCC at grades M60, M60 and M70

\section{Split Tensile Test Results}

The results of the split tensile strength test for all design mix are presented in Table XII. The Tensile tests results revealed an increased value with curing days for all SCC and NVC. The tensile strength for SCC (with Calcium Carbonate Filler + RHA $(2.5 \%)$, is $12-24 \%$ higher than SCC (with Calcium Carbonate Filler only), SCC (with Calcium Carbonate Filler + RHA (5\%) and Normally Vibrated Concrete (NVC). Fig. 12 also shows the variation of split Tensile strength with curing days. Generally, SCC design mix have higher tensile strength than NVC.

TABLE XII: SPLIT TENSILE TEST AT DIFFERENT GRADES

\begin{tabular}{rcccc}
\hline \hline \multirow{2}{*}{ No. of Days } & SCC with powder only & SCC with powder + RHA (2.5\%) & SCC with powder + RHA (5\%) & NVC \\
\cline { 2 - 5 } & M70 (All-In-Aggregates) & M70 (All-In-Aggregates) & M70 (All-In-Aggregates) & M70 (All-In-Aggregates) \\
\hline 7 & 2.3 & 2.8 & 2.7 & 2.5 \\
14 & 3.5 & 4.5 & 4.2 & 3.2 \\
21 & 4.3 & 5.2 & 4.8 & 4.1 \\
28 & 4.7 & 5.8 & 5.1 & 4.4 \\
\hline \hline
\end{tabular}

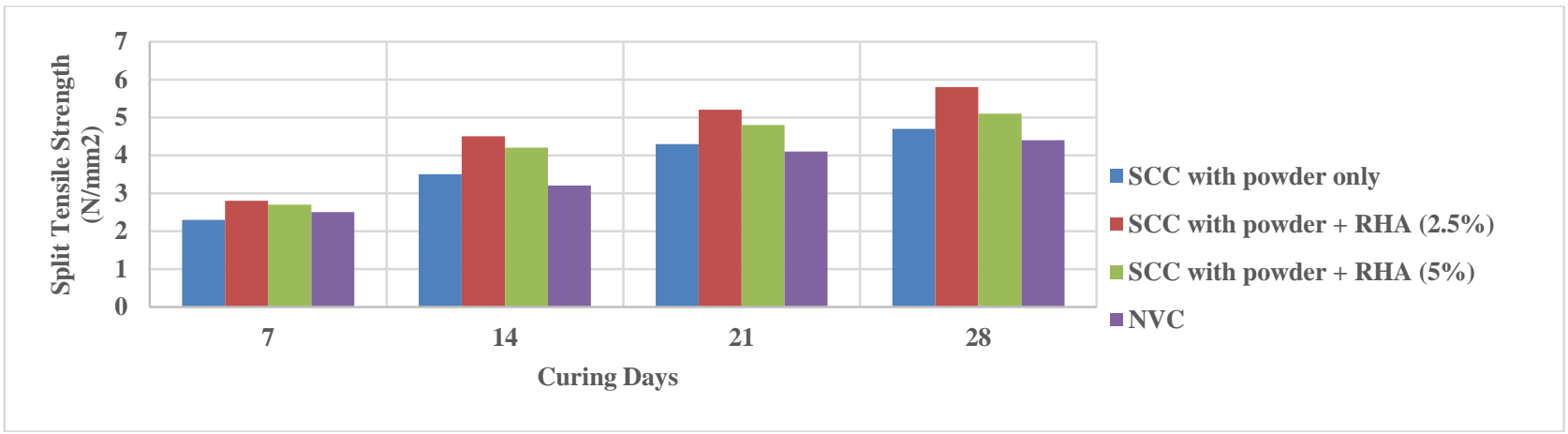

Fig. 12: Variation of Split Tensile Strength and types of SCC at grades M70

\section{CONCLUSIONS}

The following conclusions were drawn from this research:

i. SCC design mixes of grade M60, M65 and M70 prepared with $10 \mathrm{~mm}$ and $20 \mathrm{~mm}$ coarse aggregates exhibited lower slump spreads than the SCC mix produced with $6.3 \mathrm{~mm}$ coarse aggregates. Therefore, better workability will be attained from SCC when prepared using smaller coarse aggregate sizes of 6.3 iv. $\mathrm{mm}$ and $10 \mathrm{~mm}$.

ii. From the workability tests using V-funnel and L-Box apparatus, it was established that SCC will be able to attain consistency and self-compatibility under the gravity of its own weight without any need for vibration or compaction. Though, slightly lower with the addition of Calcium Carbonate Filler.

iii. The compressive strength and split tensile strength generally, increases with increase in addition of RHA $(\leq 5 \%)$ at 28 days curing. Addition of Calcium Carbonate Filler tends to increase strength and densities of the specimen. The rate of water absorption at 28 days curing for all specimen with filler was also reduced. Therefore, the addition of mineral and chemical admixtures to SCC causes it to attain split tensile and compressive strengths greater than is achieved in NVC although for certain admixture percentages the compressive and tensile strength of SCC may develop over a longer period of time.

The addition of RHA generally resulted in favorable outcomes such as increased strength and workability and is highly recommended for all SCC mixes. The SCC prepared with addition of $2.5 \%$ RHA resulted in better strength results than SCC prepared with $5 \%$ RHA addition.

v. The time of construction for SCC is shorter than the time of construction for NVC since no time is expended in any form of compaction or vibration of the concrete mix.

vi. RHA is an environmental waste which should not be discarded but its ash be re-used as mineral additive in SCC. 


\section{REFERENCES}

[1] S. Nan, H. Kung-Chung and C. His-Wen. A simple mix design method for self-compacting concrete. Cement and Concrete Research, Vol. 31, pp. 1799-1807, 2001.

[2] D.A. John. Concrete Petrography, A Handbook of Investigative Techniques. Wiley \& Sons, New York, 1998.

[3] K. Johansen and T.A. Hammer. Drying Shrinkage of Norwegian Self Compacting Concrete. SINTEF Trondheim. 2002.

[4] N. Nagamoto, and K. Ozawa. Mixture Proportions of Self-Compacting High Performance Concrete. ACI international, SP - 172, pp. 623 636, 1997.

[5] C. Valeria, M. Giacomo and R. Tarun, Characterization of marble powder for its use in mortar and concrete, Constr. Build. Mater. 24 (2010) 113-117.

[6] S.A. Rizwan, T.A. Bier. Blends of limestone powder and fly-ash enhance the response of self-compacting mortars, Constr. Build. Mater. 27 (2012) 398-403

[7] G. Sua-iam, N. Makul, Utilization of limestone powder to improve the properties of self-compacting concrete incorporating high volumes of untreated rice husk ash as fine aggregate, Constr. Build. Mater. 38 (2013) 455-464.

[8] H. Okamura. Self-Compacting High-Performance Concrete. Concrete International, pp. 50 - 54, 1997.
[9] K. Ozawa. Development of High Performance Concrete Based on the Durability Design of Concrete Structures. EASEC - 2, vol. 1, pp. 445 450. 1989.

[10] S. Kuroiwa. High Performance Concrete in Severe Environments. ACI $S P-140$, pp. $147-161.1993$.

[11] ASTM C618 - 78: Standard Specification for Fly Ash and Raw or Calcined Natural Pozzolan for Use as A Mineral Admixture in Portland Cement Concrete, ASTM International, West Conshohocken, PA. 1978.

[12] BS EN 12350-8: Testing Fresh Concrete. Self-Compacting Concrete. Slump-Flow Test. British Standards Institute. London, U.K. 2010.

[13] BS EN 12350-9: Testing Fresh Concrete. Self-Compacting Concrete. V-Funnel Test. British Standards Institute. London, U.K. 2010.

[14] BS EN 12350-10: Testing Fresh Concrete. Self-Compacting Concrete. L Box Test. British Standards Institute. London, U.K. 2010.

[15] EFNARC. Specification and Guidelines for Self Compacting Concrete. www.efnarc.org. 2005.

[16] BS EN 12390-3: Testing Hardened Concrete - Part 3: Compressive Strength of Test Specimens. British Standards Institute. London, U. K. 2002.

[17] BS EN 12390-6: Testing Hardened Concrete -Split Tensile Strength of Test Specimens. British Standards Institute. London, U.K. 2000.

[18] A.M. Neville: Properties of concrete. 3rd edition, Pitman publishing limited 39 Parker street, London WC2B 5PB, ISBN 0-273-01641-5, 158-160, 433-451. 2011. 